\title{
“Angel Investors" in Entrepreneurship: An Assessment on Turkey Model
}

\author{
Hidayet TIFTIK \\ Turgut Özal University, \\ Etlik - Keçiören / Ankara, Turkey \\ htiftik@turgutozal.edu.tr
}

\author{
Mustafa ZINCIRKIRAN \\ Dicle University, \\ Faculty of Economics and Administrative \\ Sciences, Diyarbakır, Turkey \\ mustafa.zincirkiran@dicle.edu.tr
}

\begin{abstract}
Since the subject of angel investors is a new concept for the researches of our country there is little if any in Turkey regarding of scientific research. As well as any quantitative research not exist on the field, the searches carried out are discussed as qualitative and literature study. The concept is ranked among the titles such as business angels, angel capital, angel investment, angel financing in the international literature.

The search involves the entrepreneurship concept, the study results hereof in our country, the literature about angel investment and the studies carried out in other countries regarding of the subject matter. In consequences of the searches, the subject discussed from a different point of view and headed by the literature offers a number of suggestions and advices to entrepreneurships, the whole parts modeled by angel investment and researches.
\end{abstract}

Key words: Entrepreneurship, entrepreneur, venture capital, angel investment, angel entrepreneurship, business angels

\section{Introduction}

The entrepreneurship concept was discussed in many ways in the related literatures and researches besides that it was begun to be used in the literature for the first time in earlier years of 19. and 20. century by French economist Cantillon. In regard of the searches, the entrepreneurship means to take risk according to some people; while others say that it is to have a set of administrative abilities. The scientists concern entrepreneurship on a broad term as engagement in business, risk taking, value displacement, and pursuit of opportunities, business development and innovation (Aytaç, 2006).

The modern-day sense of entrepreneurship occurs as engagement in a new business or incorporation though it's meaning of performing new grounds. Accordingly, 
the process both incorporation process and creating innovative businesses may be assessed within the context of entrepreneurship (TUSIAD, 2002).

In regard of the studies conducted about entrepreneurship culture in Turkey, it becomes important to say Turkish people reflect their ancient socio-cultural features to the business life. Given that social differences have various effects on all areas, an American, Japanese, and a Turkish entrepreneurship's sense of businesses will be a far cry from each other.

With respect to a research conducted on American and Japanese students in parallel with this issue, Americans are concluded as the most reformists (Morris, 1994).

There is not much academic literature in Turkey about angel investment which is known to be a new model in entrepreneurship. Although the scope of application of the model has been expanding slowly, it can be said awareness level of the model is quite low. The concept of angel investment defines models actively participating in providing social, physical, technological and human resources to entrepreneurs rather than sole finacial resources like taking part in managament, providing sales and marketing support, recruiting and educating and enabling them to benefit from their own Networks.

The study comprises evaluations about the recently known angel investment model and the place of the model in the entrepreneurship culture of Turkey. Besides the studies carried out on angel investment, evaluations and suggestions about the advantages and disadvantages of the model for our entrepreneurs are also within the scope of the study.

\section{Entrepreneurship Culture in Turkey}

It is significant to take into account of the general characteristics of Turkish People in order to comprehend the life styles of Turkish entrepreneurships in business life. Accordingly Turkish people are committed to traditions, adopt social behavior rules, have an introvert characteristic. Furthermore a strong bureaucratic structure exists reaching to Ottoman. As a matter of negative facts, though an industrial society, it has characteristics of individual behaviors rather than partnership, and is lack of discipline. For the sake of competition, share becomes major to provide coalition, to grow as incorporated and to catch information age (Kuvan, 2007).

In point of cultural facts, the entrepreneurship in Turkey goes back a long way. Ahi community founded by Turks who migrated from Middle East in the period of Anatolian Seljuk is one of the best examples. Within the interim period till the last times of Ottoman, trade was the possession of Non Turk Ottoman citizens; subsequent business organizations founded by the following years in general belonged to Turkish people (Oneren, 2012).

Turks according to Ulgener; have characteristics of austerity arriving till the current age within the effect of Ottoman period, avoidance of risk and individual entrepreneurship, regarding the work as an obligation, working intensively and short time, non-planning the future (Ulgener, 2006). 


\section{The Characteristics of the Entrepreneurs in Turkey}

The unequal perspective and characteristics of entrepreneurs come into prominence compared to non-entrepreneurs. According to Demirci and Tikici, entrepreneurs have three key features as vision, mission and ambition. These people think in a forward looking way, motivate themselves and have "self-aware" aspects. They are more resistant to the stress, more solution oriented to the problems and have individually a more dominant character (Demirel and Tikici, 2004).

In accordance with another approach, the individual alongside with the characteristics of society and entrepreneurship is affected on large scale by his current society's social structure, technologic substructure, economic activities and education condition and it is assumed that these elements form the intellectual substructure of the individual in terms of entrepreneurship (Ersoy, 2010).

In parallel with this approach the interaction of the entrepreneurship's success with the environment is pointed out in Figure 1 as below.

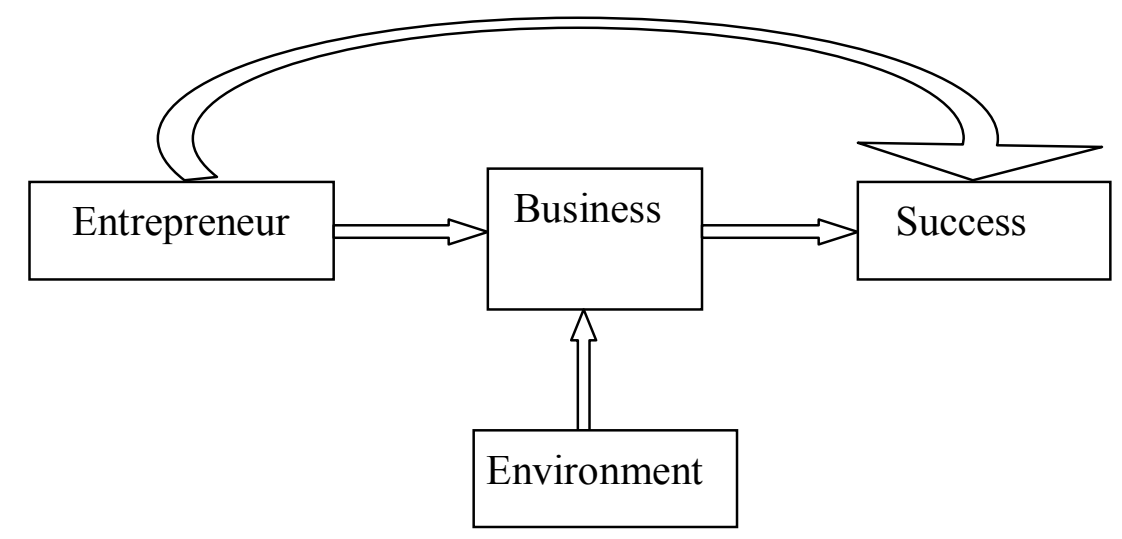

Figure 1. The Role of the Environment on the Relation between Entrepreneur and Success

Source: Bosma et al., 2000

In line with Figure1 the entrepreneur and environment determines the structure of the business. A set of characteristic variables shall be included into the circle in order to regulate the effect of the environment (Bosma et al., 2000).

The searches state that the characteristics of entrepreneur and entrepreneurship differentiate in parallel with the culture of the society. For example, multidimensional culture searches of Hofstede provide the transnational differences of values, beliefs, business roles. In that frame, Hofstede delivers beneficial studies in defining the characteristics of culture dimensions that tie with potential entrepreneurship behaviors, which will assist to state the relation between culture and entrepreneurship. Upon a search about innovation that was executed for cultural dimensions of entrepreneurship with more than 1800 human subject in many countries, Hofstede reveal that some cultures manage the entrepreneurship better than other cultures. In individual cultures, an increasing entrepreneurship tendency is the subject matter. Furthermore he defines the entrepreneurship tendency as the component of motivation and innovation (Hofstede, 1980). 
In our country searches about entrepreneurship were put forwards on different parts of the society (students, teachers, instructors, businessmen, youths, women etc.). Upon a study various approaches were revealed about the current entrepreneurs and potential entrepreneur candidates in Turkey. In that frame, lack of education in entrepreneurship, deficient of government promotion, finance problem, technologic incapacity, shortness of labor force and information on R\&D, weakness of individual skills, psychological elements were stated as negatively. However ambition on entrepreneurship, being innovative and ability to notice the opportunities, involving a young and dynamic population, decision making and risk taking abilities, the broad scale of entrepreneurship areas, which are various according to sex were revealed as positively. As well as entrepreneurship and entrepreneurs have been affected negatively or positively from parental, cultural, social, psychological, environmental elements and regional differences, the focus point is that the entrepreneurship characteristics are based on individual abilities, financial possibilities, the structure of enterprise, visionary perspective and etc (Emsen, 2001, Arslan, 2002, Akyüz et al., 2006, Börü, 2006, Büte, 2006, Kınay, 2006, Cansız, 2007, Bektaş and Köseoğlu, 2007, Kuvan, 2007, Karabulut, 2009, Naktiyok and Timuroğlu, 2009, Çarıkçı and Koyuncu, 2010, Demirel and Tikici, 2010, Kayalar and Ömürbek, 2010, Patır and Karahan, 2010, Karahan, 2010, Demirel and Tikici, 2010, Durak, 2011, Ören and Biçkes, 2011, İşçan and Kaygın, 2011, Korkmaz, 2012, Öneren, 2012, Bozkurt et al., 2012, Çiçek and Durna, 2012, Uygun et al., 2012, Bilge and Bal, 2012, Kilıç et al., 2012, Akyürek and Şahin, 2013).

The negative and positive aspects of the entrepreneurs and entrepreneur candidates based on the current findings are listed as in the table below.

Table 1.The Aspects of the Entrepreneurs in Turkey

\begin{tabular}{|l|l|}
\hline \multicolumn{1}{|c|}{ Positive aspects } & \multicolumn{1}{|c|}{ Negative aspects } \\
\hline - Young and dynamic & - Indecisive \\
- Willing to take risk & - Scared of taking risk \\
- Gifted for entrepreneurship & - Anxiety of deficient capital \\
- Open to technology & - Inability of competition or \\
- Brave and ambitious on enterprise & avoidance of competition \\
- Making difference & - Individual problems based on socio \\
- Genetic entrepreneur spirit & - Dsychology \\
- Innovative perspective & - Lack of R\&D culture \\
- Honest and confidential & - Imitator \\
- Open to education & - Hurriedness (get rich in the brief \\
- Ambition of growing & \multicolumn{2}{|c|}{ way and reach to the point) } \\
\hline
\end{tabular}


According to the Entrepreneurship Report by TUSIAD announced in 2002, most of the entrepreneurs perceive that Turkish entrepreneurs do business to "strike it rich". Though the negative assessment of the society, it has been observed that people wish to be entrepreneur. In Turkey "statism" is a so much rigid norm that the ration of people who say "business properties shall belong to state" is at the same level of people who say "shall be private". This similar rating is valid for the individuals who consider the subsistence liability shall be under the control of the state or otherwise individual himself. Upon the perspective of the society to the competition, another significant indicator similar like state and individual relations, the competition in Turkey is welcomed warmly however the ratio of individual who have negative perception against competition is highly on increase when compared to the other countries. The studies carried out show that less educated citizens have more statism tendencies and characteristics than well-educated citizens who look competition in a positive light. Accordingly, contributing to the level of education will have effects on decrease in statism mentality and proliferation of entrepreneurship values (TUSİAD, 2002).

According to Tekin, the societies which have entrepreneurship culture and benefit from it properly in line with the aims of entrepreneurship policy will experience success. A new entrepreneur culture shall be constituted to grow up favorable entrepreneur type. Principal characteristics that entrepreneurs shall have to form such kind of culture are as follow (Tekin, 1998):

$\checkmark$ Entrepreneur should see the world market in first hand.

$\checkmark$ Entrepreneur should perceive free market and competition environment as the basic reason of existence.

$\checkmark$ Entrepreneur should continually experience information development and change, perceive such change as an opportunity and benefit from it properly in line with his aims.

$\checkmark$ Entrepreneur should tend to take lessons from ancient and current experiences.

$\checkmark$ Entrepreneur's success motivation, commitment, desire and self-reliance should be high3er.

$\checkmark$ Entrepreneur should have ability to take risks.

\section{Angel Investments}

It is significant to emphasize the concepts "Venture Capital" or "Private Equity" that share similarity with angel invest or angel investment before initializing with definitions.

Venture capitalists are divided into two as individual and institution ones according to the searches. It is called as angel investors supplying individual venture capital, venture capitalists supplying institutional funding (Gunay et al., 2011).

Primarily private equity concept comprising of venture capital means enlargement and up growth investments targeting the companies for 3-10 years which conduct and follow acquisitions, reconstructing, and growth strategy as well as the ideas and investments committed to new based companies at start-up phase. In that parallel private equity shall be expressed as long term investment supplied by investors keeping of fund surplus in order to form and function highly developmentally potential small and medium sized enterprises (CMB, Capital Markets Board, 2010). 
Secondly venture capital by the companies keeping of fund surplus which produce new ideas or technology is the investment mean of equity capital and so forth supplied to SMEs open for improvement in consideration of future share (Yavuz, 2008).

In accordance with another approach, venture capital is well organized portfolio management institution that provides the finance of the investment projects, which couldn't find the opportunity to put into practice because of lack of resources and have a high potential success in the future, through founding new companies and possessing voting power and that aims to benefit from price escalations with the aids of potential profits and certificates stock (Rodoplu, 1993).

In article 3 of "Venture Capital Investment Partners Principal Notification" (Serial VIII, No: 21) announced in Official Gazette dated of 6 July 1993 and 2169 numbered and published by Capital Markets Board (SPK) venture capital is defined as follow. Venture capital (VC) is long term resource transfer form that is established or will be established in Turkey, has a high-potential development capacity and is formed through investing on venture capitals exported at first hand markets via enterprise companies whose stocks and bonds have less liquidity (Tuncel, 1995).

Venture capital like other finance methods is a finance management enabling effective and efficient application of resources of the enterprises. As in other methods, the elements to increase the success possibility of such method are to determine the necessities, to form a stable plan for the future and to be realistic in identification of the goals (Kugu, 2004).

Most of the studies show that venture capitalists have an active role in their related invested company through supplying business consultancy, strategic consultancy, innovative manufactures to the market, transferring the experiences of senior executives (Denis, 2004).

Upon the general definitions mentioned above venture capital shall be stated as a financial model which supply funding to the enterprises (generally SMEs) that start with a new business idea or have enlargement goal but do not have sufficient finance and let them grow up, which a set of experiences about management and specialty are transferred, as well as perceived as a mean of profit achievement or a kind of investment.

Angel term is used primarily by stock speculators in Broadway to tell about the rich who makes risky investment in order to continue Broadway shows (Karabayır et al., 2012). Following the international literature it is used with such terms as "business angels, angel invest, angel investment investment, angel capital, angel finance".

There are various definitions of angel investment called in different names as mentioned above. For example according to Osnabrugge, angel capital is a finance model which is supported by private investors possessing an amount of accumulation on business to the enterprises beginning with their own resources and at the first phases and which includes also the partnership (Osnabrugge, 2000).

According to Mayfield, angel investors are; "unscientific venture capitalists investing capitals on new formed firms." (Mayfield, 2000, trns. Karabayır et al.).

In regard of common approaches of different researchers angel investors are stated as models that take active roles in not only finance support issues such as participating 
into the management, support for sales and marketing, employment and training of the workers, let the entrepreneur benefit from their own social networks but also in support for social, physical, technological and human resource (Landström, 1998, Tashiro, 1999, Wiltbank et al., 2009).

There is only one qualitative, and very few literature studies on angel invest, angel investment (Ozdogan, 2001, Aypek, 2002, Uluyol, 2008, Uckun, 2009, Karabayır et al., 2012). It demonstrates that awareness of angel investment in Turkey is at the lowest levels in terms of academically studies.

When we look at the international works, it is possible for the recent 30 years to encounter with the studies about venture capital, private equity and after then angel investment which discuss with different dimensions. In such studies, the relations of angel investors with the firms that they have supported investment, various opportunities in any kind supplied to them (management support, marketing, sale, manufacture methods, partnership, finance, information and experience transfer etc.) are discussed. In addition to these, the share and ratio of the angel investment within other kinds of the investments in which countries the subject matter are of the studies, the behaviors of the angel investors, sex differences, sectoral distributions and cultural variations are addressed (Wetzel, 1982, Wetzel, 1983, Mason and Harrison, 1997, Prowse, 1998, ACS et al.., 1998, Sohl, 1999, Liu, 2000, Mason and Harrison, 2002a, Mason and Harrison, 2002b, Freear et al.., 2002, Holaday et al.., 2003, Sohl, 2003a, Sohl, 2003b, Mason and Stark, 2004, Sohl, 2006, Harrison and Mason, 2007, Ibrahim, 2008, Sohl, 2008, Wong et al., 2009, Shane, 2012).

In concerning of Uluyol's studies, an individual who has a business idea is lack of the necessary finance to support such idea and if the sufficient finance not be able to be found many valuable business ideas vanish before coming true. For that reason, the method of angel finance, as a new finance model, in that phase is estimated to be a possible solution (Uluyol, 2008).

Uckun, 2009, perceives angel investors as an alternative model in terms of SMEs' finance, and states that angel investors in company with their knowledge and experience will constitute a synergy through making the dreams of new entrepreneurs come true together with appointing resources to SMEs who have financial problems and so the scarce resources will be prevented to disappear in the related domestic economy in the way that the risk will be diminished as well as SMEs will be prevented to go bankrupt (Uckun, 2009).

Various concepts used for angles may be briefly described as follows (Saublens and Reino, 2008; trns.Uluyol, 2008);

Virgin Angel: Those who will support a project for the first time.

Latent Angel: Those who have not made any angel investment in the last three years, but have a past experience in this area.

Welfare Maximizing Angel: Those who have previously supported and is currently supporting a number of projects as an experienced businessman.

Entrepreneur Angel: Those who have the spirit of entrepreneurship, have a good financial standing, are engaged in several different sectors and have investors in the exchange market. 
Income-Seeking Angel: Those who desire to generate income or business opportunities by investing a sum of capital in a business.

Corporate Angel: Corporate legal entities which invest for supporting projects.

Business Angel Network (BAN) or Business Angel Portal: Organizations which are established in order to bring business angels and entrepreneurs together. BANs are neutral in these organizations and have a position where angles and entrepreneurs that are suitable for each other have the opportunity to meet.

Matching Process: The stage in which entrepreneur and business angel are matched (come together to do business).

Agreement/Matching: The stage in which angel and entrepreneur make a partnership agreement.

Investment Forum: Presentation meetings where entrepreneurs present their projects to the angels interested in their projects for a period of 15-20 minutes.

Business Angels Syndicate: An unofficial community established by a certain number of angels, where assessments are conducted, decisions on the use of funds are taken, personal experiences are shared under the roof of an organization.

Serial Angel: Those who contribute to more than two investments in a year.

Investment Preparation: The stage in which business angel and entrepreneur come together, listen to the demands of each other and lay the foundations of partnership. Many issues like partnership shares, mode of operation etc. are discussed in this stage.

Way Out: The stage in which business angels sell their shares and leave the enterprise they have invested in. In this case, other businesses or persons may buy these shares. The sales method used is the way out.

According to the results of the qualitative research conducted on the angel investors in our country by Karabayir et al. in 2012, it is determined that the only factor having an impact on the investment decisions of angel investors is the profitability of the investment and there is a strong relation between the dimensions of entrepreneur orientation (risk taking, innovation, proactivity) and decisions of angel investors. Furthermore, it is understood that new enterprises undertaken by angle investors apart from capital investments play an important role in marketing, financing and management decisions (Karabayır et al., 2012).

In the light of the researches conducted, angel investment may be defined as a funding method in which big business enterprises provide the financing needed by real persons or legal entities having a new business idea through a partnership agreement with a certain percentage of shares.

In addition to the fund needed by the party supported by angel investment, the angel investors also provides management support, marketing and sales support, knowledge and experience exchange, technology and R\&D support etc. Thus, especially the small-scale businesses and investors develops and grows and take root in the market.

However, it should be noted that the dimension of percentage in this partnership should be clearly determined, considering the contribution to the sector by the party having a new business idea. Otherwise, it is possible that the "angel investor" may 
impose on the party needing support. At this point, there is a possibility for the investors to stop being an angel due to the fact that angel investment culture has not been settled yet in our country, qualitative academic researches fail to satisfy and the supported party may gain an income less than the expected amount

Relationship of the parties in angel investment before and after the investment and the possible results are indicated in the following Figure 2.

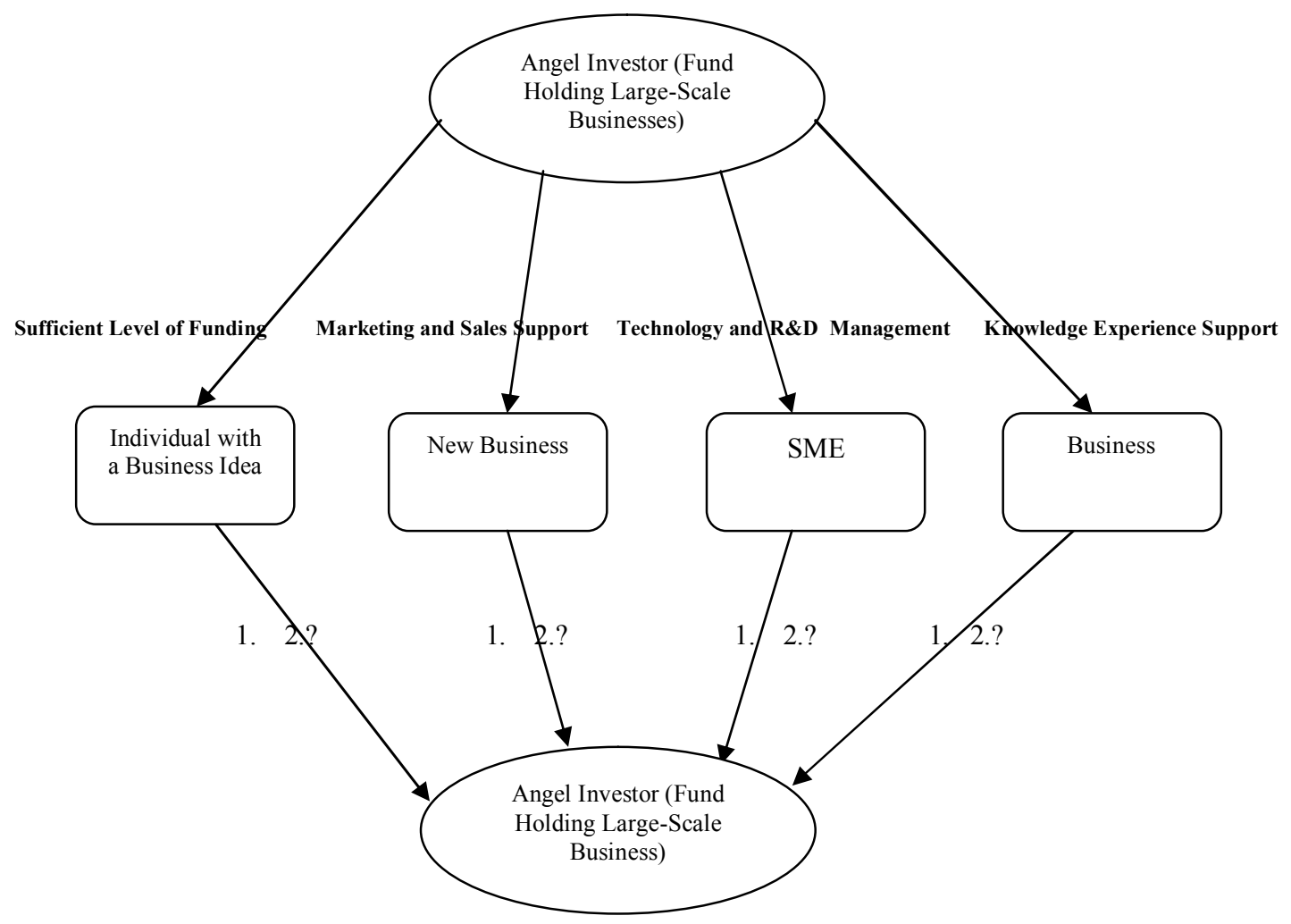

Figure 2. Parties in the Angel Investment Relationship and Possible Results

On the basis of the information and findings obtained from the researches, business relationships between the parties of "Angel Investment" are indicated in the Figure 2. In the figure, there are those needing the support of fund holding large-scale businesses, private individuals having a new business idea, enterprises newly taking step in the business life, SMEs and enterprises desiring to grow. Angel investor provides sufficient funding, marketing and sales support, technology and R\&D support, management, knowledge and experience support depending on the type of support needed. One or all of these supports may be provided, as required by the case. Types of these supports may be increased. In the 1st case expected to occur in the end of the process, all parties supported turn into a new angel investor in a certain period of time. However, at this point, there is a possibility that parties needing support may be exploited by the angel investor and become vanquished even before starting in the 2 nd case indicated with a question mark (2), which we question and deem probable. It is suggested that the 2nd case is totally contrary to the basic point of origin; but it is a case which should be questioned. This situation may be understood more clearly if qualitative researches on the subject for both parties are conducted. 


\section{Angel Investors in Turkey and Success Cases}

In an article published in a website named "kobilersizinicin.com" where evaluations are made and issues are discussed in relation to SMEs, "Investments of families and friends unexceptionally play a critical role in the entrepreneurship ecosystem in Turkey. Even if it is not possible to statistically prove, it is possible to believe in this assumption by making a cultural generalization. However, for companies with a high potential of growth to gain acceleration, more challenging semi-official commercial investment solutions should be developed in addition to the small amounts of savings provided by families and friends. In developing countries like Turkey, it is an obstacle considerably difficult but needed to be overcome that commercial cooperations with the people we do not closely acquainted with and non-institutional groups do not develop due to the fact that we do not trust in our power of sanction and in the system. Let's make a simple proportioning. Considering USA's population of 313 millions and Turkey's population of 79 millions; if there are 250 thousand angel investors and 791 venture firms in USA, we should target 63 thousand local angel investors, investment in 120 thousand 620 companies and 43 agreements with 181 local venture firms in Turkey. Today, number of known and unknown investors is not more than thousand and number of local venture firms attempted to be formalized is utmost 20. METUTECHBAN and Galata Business Angels Network, having rapidly gained prestige in Turkey, take the initiative of a local angel investment movement. As focused by Endeavor, it is evaluated that "We should rapidly and extensively progress by taking firm steps in order to develop the entrepreneurship ecosystem for increasing the number of "Large-Scale Businesses of the Future" (LSBF).

The foregoing evaluation shows that Turkey falls behind in angel investment when its population is taken into consideration. It is possible to say that this is the impact of different cultural and entrepreneurship viewpoints of entrepreneurs operating in our country.

According to the researches that we have conducted on Internet as of January 2014, there are 12 companies of angel investment network which were organized in Turkey and currently provide support in terms of angel investment (http://www.dinarstandard.com/angel-investors-and-venture-capitalists-in-turkey/). This figure does not include the enterprises which are not organized, but support individuals or companies having new business ideas. These enterprises provide services for those willing to invest in Information and Communication Technology, Life Sciences (Biotechnology and health), Advance Microelectronics, Advance Material, Internet Technology, E-Commerce, Textile, Food, Education, Tourism, Health and other service sectors through their angel investment network. The oldest of these companies have been serving for nearly 18-20 years. Apart from this one, other companies have been giving angel investment consultancy services in Turkey for approximately 8-10 years.

Furthermore, Turkish version of Dragons' Den program organized by an angel investment network included in the foregoing figures and previously carried out especially in order to motivate young businessmen candidates in England. There is also another program named "Do you have any idea?" published with the same sense and presented by another angel investment company and both programs draw attention particularly of young entrepreneur candidates. This once more proves the need for angel 
investors in our country. Considering the fact that the major problem of entrepreneur candidates in our country is the need for capital, the reason behind this interest in these kinds of programs will be better understood. As a society watching television too much, the number of these kinds of programs may be increased in order to extend "angel investment model" especially to the young people more quickly and easily. Informing young entrepreneur candidates who use social media actively through the Internet may be utilized as another important means.

\section{Discussion and Suggestions}

Even if the concept of "Angel Investment", which is new for our country and virtually different from other financing types, is applied in our country to a certain extent, it should not be disregarded that it is still not known by a large part of the society. Due to its social and cultural structure, Turkey is the country of people who have a low level of trust in each other. In this regard, it may be expected that the concept of angel investment will not be very popular in Turkey. There are also other concerns about angel investment, such as the headiness of our people to become rich, their tendency to not take risks, their desire to hit the jackpot, counterfeiting and weakness of technological infrastructure.

Looking into the subject in terms of the favorable characteristics of entrepreneurs and entrepreneur candidates in our country; presence of a young and dynamic society, openness to the idea of innovation, dynamism in following up technology and need for education in the area of entrepreneurship are promising for the development of angel investment in our country.

In consequence of the approaches and evaluations presented, the following suggestions may be made to those concerned for the entrepreneurship and angel investment. Some of the following suggestions are quoted from 2011-2013 SME Strategy Action

Plan (http://www.oka.org.tr/ContentDownload/GirisimcilikRaporu.pdf).

$\checkmark$ Extending the entrepreneurship culture to the entire society and improving the entrepreneurship environment so as to reach a level comparable to the developed countries,

$\checkmark$ Providing education and consultancy services on entrepreneurship and angel investment for potential young entrepreneur candidates,

$\checkmark$ Enhancing the importance attached to entrepreneurship in the curriculum,

Carrying out activities to encourage entrepreneurship such as contests, awards and promotions,

Establishing structures like "Entrepreneurship Council" in order to ensure coordination between organizations,

Providing services of workplace, office, education and consultancy for new enterprises to be founded by entrepreneurs and thus ensuring growth,

Conducting informative programs about angel investment on radio, television and Internet,

Rapidly putting into practice government incentives to promote angel investment, 
Ensuring that academicians carry out qualitative researches on the subject in order to eliminate the hesitations on angel investment in the minds of parties,

$\checkmark$ Carrying out joint activities in every area (business world, academia, researchers) with countries experienced in angel investment.

To sum up, when the angel investment companies in our country effectively evaluate the business ideas presented to them and bring profit for both the owner of the idea and the company making the investment, they will have the role of "angle". If, however, owner of the business idea, which is expected to bring a high income, is not provided with a profit corresponding to the value of the idea and the angel investment company acts with the logic of "Only I'll earn", it may be the "devil". This is totally contrary to the basic logic of angel investment.

It is required to make comprehensive qualitative researches involving all parties (investors, enterprises, owners of new business ideas, entrepreneurs, entrepreneur candidates, young people, academicians) in order to better understand the subject. Literature aspect of the research and different dimensions of the relevant discussions are important for lighting the way for future studies.

\section{References}

Acs, Zoltan J., and Fred A. Tarpley Jr.(1998). "The angel capital electronic network (ACE-Net)." Journal of Banking \& Finance 22.6 p.793-797.

Akyürek, Çisem, ve Çavuş, ŞAHİN.(2013). "İlkokul Öğretmenlerinin Girişimcilik Becerisine İlişkin Görüşlerinin Değerlendirilmesi”, EKEV Akademi Dergisi, Y1l: 17 Sayı: 57

Akyüz, Kadir. Cemil., Gedik, T., Akyüz, İ., \& Yıldırım, İ. (2010). "Rize İlindeki Lise ve Üniversite Öğrencilerinin Girişimcilik Yeteneklerinin İncelenmesi” İktisadi ve İdari Bilimler Dergisi, 20/1

Arslan, Kahraman. (2011). "Üniversiteli gençlerde mesleki tercihler ve girişimcilik eğilimleri." Doğuş Üniversitesi Dergisi 3.2 s.1-11.

Aypek, Nevzat. (2002). "Kobi Finansmanı: Venture Capital Ve Angel." İktisat İşletme ve Finans 17.198 s.3-16.

Aytaç, Ömer. (2006). “Girişimcilik:Sosyo-Kültürel Bir Perspektif”, Dumlupınar Üniversitesi Sosyal Bilimler Enstitüsü Dergisi, Sayı:15, Ağustos 2006:139160.

Çetin, Bektaş, Mehmet Ali Köseoğlu; "Aile İşletmecilik Kültürünün Girişimcilik Eğilimine Etkileri ve Bir Alan Araştırması", Karamanoğlu Mehmet Bey Üniversitesi, İ.İ.B.F. Dergisi, Y11:9, Sayı:13, Aralık 2007.

Bilge, Hürriyet, and Vedat BAL. (2012)."Girişimcilik Eğilimi: Cela Bayar Üniversitesi Öğrencileri Üzerine Bir Araştırma" Journal of Süleyman Demirel University Institute of Social Sciences Year 2.16

Bosma, Niels, Mirjam Van Praag, and Gerrit De Wit. (2000). "Determinants of successful entrepreneurship." Research Report 0002/E

Bozkurt, Özlem Çetinkaya.(2011). Başarılı Girişimciler ve Öğretim Üyelerinden Öneriler, Detay Yayıncılık, Ankara 
Bozkurt, Özlem Çetinkaya, Alparslan, Ali Murat, (2013) "Girişimcilerde Bulunması Gereken Özellikler İle Girişimcilik Eğitimi: Girişimci ve Öğrenci Görüşleri” Girişimcilik ve Kalkınma Dergisi, Journal of Entrepreneurship and Development, 8.1

Börü, Deniz. (2006). "Girişimcilik eğilimi: Marmara Üniversitesi İşletme Bölümü Öğrencileri Üzerine Bir Araştırma”, Marmara Üniversitesi, Sosyal Bilimler Enstitütüsü Yayını, No:6, İstanbul

Büte, Mustafa. (2006). "Trabzon İlinde Girişimcilik Özellikleri Araştırması." Uluslararası Girişimcilik Kongresi Bildirileri Kitapçığı, Bişkek

Cansız, Emine.(2007) “Üniversite Öğrencilerinin Girişimcilik Özelliklerinin Belirlenmesi: Süleyman Demirel Üniversitesi Öğrencileri Üzerine Bir Çalışma. Süleyman Demirel Üniversitesi, Sosyal Bilimler Enstitüsü, Yüksek Lisans Tezi, Isparta

Çarıkçı, İlker Hüseyin, and Osman Koyuncu.(2010) "Bireyci-toplumcu kültür ve girişimcilik eğilimi arasındaki ilişkiyi belirlemeye yönelik bir araştırma." Mehmet Akif Ersoy Üniversitesi, Sosyal Bilimler Enstitüsü Dergisi 3 (2010): $1-18$.

Çiçek, Recep ve Durna, Ufuk.(2012)."Meslek İdealleri ve Girişimcilik Niyetleri" Mustafa Kemal Üniversitesi Sosyal Bilimler Enstitüsü Dergisi Yıl: 2012 Cilt: 9 Say1: 17, s. 17-31

Demirel, Erhan. T. ve Tikici, Mehmet. (2004). “Kültürün Girişimciliğe Etkileri”. Doğu Anadolu Bölgesi Araştırmaları, 2(3), 49-58.

Demirel, Erkan T., ve Tikici, Mehmet.(2010). "Üniversite Öğrencilerinin Girişimcilik Özelliklerinin Beyin Baskınlık Analizi İle Değerlendirilmesi” Electronic Journal of Social Sciences 9.32

Denis, David J.(2004). "Entrepreneurial finance: an overview of the issues and evidence." Journal of Corporate Finance 10.2 p.301-326.

Dura, İbrahim. (2011). "Girişimciliği Etkileyen Çevresel Faktörlerle İlgili Girişimcilerin Tutumları: Bir Alan Araştırması” Yönetim Bilimleri Dergisi 9.2 s. 191.

Emsen, Ömer.(2001). "Genç Nesilde Mesleki Eğilimler ve Girişimcilik: Ampirik Bir Çalışma." Milli Prodüktivite Merkezi, Verimlilik Dergisi 2001/1 s.153-176.

Ersoy, Hüseyin.(2010). "Kültürel Çevrenin Girişimcilik Tercihine Etkisi." Organizasyon ve Yönetim Bilimleri Dergisi 2.1 s.71-77.

Freear, John, Jeffrey E. Sohl, and William Wetzel.(2002). "Angles on angels: financing technology-based ventures-a historical perspective." Venture Capital: An International Journal of Entrepreneurial Finance 4.4 p. 275-287.

Günay, Suleyman Gokhan ve Başalp, Ahmet. (2011). "Girişimciler, Melek Yatırımcılar ve Risk Sermayesi Firmaları Arasında Kurulacak Bir Ağ, Bu Ağın Yapısı ve Önemi." Business \& Economics Research Journal 2.2

Harrison, Richard T., and Colin M. Mason.(2007). "Does gender matter? Women business angels and the supply of entrepreneurial finance." Entrepreneurship Theory and Practice 31.3 p. 445-472.

Hofstede, Geert. (1980). Culture's Consequences :International Differences O nWork Related Values, Organizational Studies, ss.143 
Holaday, John W., Steven L. Meltzer, and James T. McCormick.(2003) "Strategies for attracting angel investors." Journal of commercial biotechnology 9.2 p.129133.

Ibrahim, Darian M.(2008). "The (not so) puzzling behavior of angel investors." Vanderbilt Law Review 61 p.1405.

İşcan, Ömer Faruk ve Erdoğan Kaygın. (2011) "Potansiyel Girişimciler Olarak Üniversite Öğrencilerinin Girişimcilik Eğilimlerini Belirlemeye Yönelik Bir Araştırma" Organizasyon ve Yönetim Bilimleri Dergisi, Cilt 3, Sayı 2

Karabayır, Mehmet Emin, Ahmet Zafer, Gülşen, vd.. (2012). "Melek Yatırımcıların Yatırım Kararlarında Girişimci Odaklılığın Rolü: Türkiye'deki Melek Yatırımcılar Üzerine Bir Araştırma" Ankara Üniversitesi SBF Dergisi, Cilt 67, No. 2, 2012, s. 69-93

Karabulut, A. Tuğba.(2009). "Üniversite Öğrencilerinin Girişimcilik Özelliklerini ve Eğilimlerini Belirlemeye Yönelik Bir Araştırma", Marmara Üniversitesi, İ.İ.B.F Dergisi, Cilt 26, Sayı, 1

Karahan, Mehmet.(2009). " A Research On Entrepreneurship Education and Determination Of Entrepreneurship Profiles Of University Students: Sample Of Inönü University" Proceedings of İnternational Entrepreneurship Congress 2009: "SMEs and Entrepreneurship, October , 14-15-16, 2009.

Kayalar, Murat, ve Nuri Ömürbek. (2010). "Girişimci Adaylarının Risk Almaya Yatkınlık Özelliğinin Cinsiyet Bağlamında İncelenmesi" İktisadi ve İdari Bilimler Dergisi, 21.1 (2010).

K1lıç, Recep, Belma Keklik, ve Nevzat Çalış. (2012). " Üniversite Öğrencilerinin Girişimcilik Eğilimleri Üzerine Bir Araştırma: Bandırma İİBF İşletme Bölümü Örneği" Süleyman Demirel Üniversitesi İktisadi ve İdari Bilimler Fakültesi Dergisi, C.17, S.2, s.423-435.

Kınay, Hasan Fehmi, (2007) “Girişimcilik, Kalkınma ve Rekabet İlişkisi, Kütahya'da KOBİ'lerin Girişimcilik Profili”’ TOBB Yayınları, Ankara

Korkmaz, Oya. (2012) “Üniversite Öğrencilerinin Girişimcilik Eğilimlerini Belirlemeye Yönelik Bir Araştırma: Bülent Ecevit Üniversitesi Örneği” Afyon Kocatepe Üniversitesi, İIBF Dergisi, C.XIV, S II, 2012

Kuğu, Tayfun, Deniz (2004), “Finansman Yöntemi Olarak Risk Sermayesi”, Yönetim Ve Ekonomi Dergisi Cilt:11 Sayı:2, Celal Bayar Üniversitesi İ.İB.F. MANISA

Kuvan, Hakan, (2007) "Türk Girişimcilerinin Yaşam ve Çalışma Değerleri: Malatya'lı Girişimciler Üzerine Bir Araştırma" Yayımlanmamış Doktora Tezi, Süleyman Demirel Üniversitesi, Sosyal Bilimler Enstitüsü, Isparta

Landström, Hans (1998), "Informal Investors as Entrepreneurs", Technovation, 18 (5): 321-333.

Liu, Ying. "An overview of angel investors in Canada." MFA paper (2000).

Mason, Colin M. and Richard T. Harrison (1997), "Business Angel Networks and the Development of the Informal Venture Capital Market in the UK: Is there still a role for the Public Sector?", Small Business Economics, 9 (2): 111-123.

Mason,, Colin M., and Richard T. Harrison (2002a): "Barriers to investment in the informal venture capital sector." Entrepreneurship \& Regional Development $14.3271-287$. 
Mason, Colin M., and Richard T. Harrison. (2002b): "Is it worth it? The rates of return from informal venture capital investments." Journal of Business Venturing 17.3 211-236.

Mason, Colin, and Matthew Stark. "What do investors look for in a business plan? A comparison of the investment criteria of bankers, venture capitalists and business angels." International Small Business Journal 22.3 (2004): 227-248.

Mayfield, William (2000), "What is Informal Venture Capital and Who are Angels?" Kansas Economic Report, Spring 2000, 28, Wichita State University, Wichita, Kansas.

Morris, H.M.,(1994) "Fostering Corparate Entrepreneurship: Cross Culturel Comparisons Of The Importance Of Induvalism versus Collectivism”, Journal Of International Business Studies, p.25-31

Naktiyok, Atılhan, ve Timuroğlu, M. Kürşat. (2010) "Öğrencilerin Motivasyonel Değerlerinin Girişimcilik Niyetleri Üzerine Etkisi ve Bir Uygulama" İktisadi ve İdari Bilimler Dergisi 23.3

Osnabrugge, Mark V. (2000), "A Comparison of Business Angel and Venture Capitalist Investment Procedures: An Agency Theory-Based Analysis", Venture Capital, 2 (2): 91-109.

Öneren, Melahat, (2012) "İç Anadolu Bölgesindeki Genç Nüfusun Girişimcilik Eğilimleri Üzerine Bir Araştırma” Girişimcilik ve Kalkınma Dergisi (7:2), Journal of Entrepreneurship and Development

Ören, Kenan ve Mehmet Biçkes.(2011). "Kişilik Özelliklerinin Girişimcilik Potansiyeli Üzerindeki Etkileri( Nevşehir'deki Yüksek Öğrenim Öğrencileri Üzerinde Yapılan Bir Araştırma" Suleyman Demirel University Journal of Faculty of Economics \& Administrative Sciences 16.3

Özdoğan, Osman N.,(2001) "Alternatif bir Finasman Aracı Olarak Angel Finanslama ve Kuşadası'nda Faaliyet Gösteren KOBİ'lerin Finanslama Yönelimleri” I. Orta Anadolu Kongresi

Patır, Sait ve Karahan, Mehmet. (2010). "Girişimcilik Eğitimi ve Üniversite Öğrencilerinin Girişimcilik Profillerinin Belirlenmesine Yönelik Bir Alan Araştırması." Business \& Economics Research Journal 1.2

Prowse, Stephen (1998), "Angel Investors and the Market for Angel Investments", Journal of Banking \& Finance, 22 (6-8): 785-792

Rodoplu, Gültekin. (1993). "Türkiye'de Sermaye Piyasası ve İşlemleri”, 1 .Baskı, İstanbul: Marmara Üniversitesi Nihad Sayar Eğitim Vakf, Yayın No: 459692, Yaylım Matbaası, s. 117.

Saublens, Christian ve Reino, Monica, (2008), "Introduction to the Activities of Regionel Business Angels Network, http://www.yban.net/document/How to Create a BAN.pdf

Shane, Scott. (2012). "The importance of angel investing in financing the growth of entrepreneurial ventures." The Quarterly Journal of Finance 2.02

Sohl, Jeffery E. (1999), "The Early Stage Equity Market in The USA”, Venture Capital: An

International Journal of Entrepreneurial Finance, 1 (2): 101-120. 
Sohl, Jeffrey E. (2003a). "The US angel and venture capital market: Recent trends and developments." The Journal of Private Equity 6.2 p.7-17.

Sohl, Jeffrey. (2003b). "The private equity market in the USA: lessons from volatility." Venture Capital: An international journal of entrepreneurial finance 5.1 29-46.

Sohl, Jeffrey E.(2006). "Angel investing: Changing strategies during volatile times." Journal of Entrepreneurial Finance, JEF 11.2 (2006): 27-47.

Sohl, Jeffrey. (2008)."The angel investor market in 2008: A down year in investment dollars but not in deals." Center for Venture Research 26

Sermaye Piyasası Kurulu (SPK), (2010) "Girişim Sermayesi Yatırım Ortaklıkları”, SPK Yatırımcı Bilgilendirme Kitapçıkları-6, Ankara

Tashiro, Yasuhisa (1999), "Business Angels in Japan”, Venture Capital, 1 (3): 259-273.

Tekin, Mahmut.(1998). “Girişimcilikte Karşılaşılan Engeller ve Çözüm Önerileri”, İş Fikirleri Dergisi, Sayı: 22, s.42, İstanbul

Tuncel, Kürşat. (1995). "Risk Sermayesi Finansman Modeli Dünya Uygulamalarının Analizi ve Türkiye İçin Özgün Bir Model Önerisi”, Ankara: SPK, Yayın No: 19, s.3

TÜSİAD, Türkiye'de Girişimcilik, Aralık 2002,. Yayın No: TÜSİAD-T/2002-12/340.

Uçkun, Nurullah.(2009). "KOBI'lerin Finansal Sorunlarına Melek Sermaye Çare Olabilir mi?", Muhasebe ve Finansman Dergisi, Say1 141,

Uluyol, Osman. (2008). "Girişimcilikte Alternatif Bir Finansman Modeli Olarak Melek Finansman Yöntemi”, Girişimcilik ve Kalkınma Dergisi, 2008, Cilt 3, Sayı 2, ss. 43-68. Çanakkale Onsekiz Mart Üniversitesi, Biga İ.İ.B.F.

Uygun, Mutlu, Mete, Sinan ve Güner, Ebru. (2012). "Genç Girişimci Adaylarının Girişimcilik Eğilimi ve Girişimcilik Özellikleri Arasındaki İlişkiler" Organizasyon ve Yönetim Bilimleri Dergisi, Cilt 4, Sayı 2

Ülgener, Sabri. (2006) “İktisadi Çözülmenin Ahlak ve Zihniyet Dünyası”, İstanbul: DerinYayınları

Wetzel, William E. (1982), "Risk Capital Research", in Encyclopaedia of Entrepreneurship, Kent, Calvin A., Donald L. Sexton and Karl H. Vesper (eds.), Englewood Cliffs, (New Jersey: Prentice Hall).

Wetzel, William E. (1983), “Angels and Informal Risk Capital”, Sloan Management Review, 24 (4):23-34.

Wong, Andrew, Mihir Bhatia, and Zachary Freeman.(2009). "Angel finance: The other venture capital." Strategic Change 18.7-8 p. 221-230.

Yavuz, Mustafa .(2008). İhracatta Alternatif Finansman Teknikleri, İGEME Yayını,

\section{Internet Sources}

https://www.kobilersizinicin.com/melek-yatirimci.aspx

http://www.oka.org.tr/ContentDownload/GirisimcilikRaporu.pdf)

http://www.dinarstandard.com/angel-investors-and-venture-capitalists-in-turkey/) 